\title{
INVESTIGATION OF THE USE OF SCRAP TYRES AS SOIL REINFORCEMENT
}

\author{
ShaAfan AbDUllah TAHER ${ }^{1, *}$, HUSSEIN JAlal ASWAD HASSAN ${ }^{* *}$ and ASAAD FARAMARZI ${ }^{* * *}$ \\ *Technical College of Engineering, Duhok Polytechnic University, Kurdistan region-Iraq \\ ${ }^{* *}$ Dep. of Civil Engineering, College of Engineering, University of Duhok, Kurdistan region-Iraq \\ ${ }^{* * *}$ Dep. of Civil Engineering, School of Engineering, University of Birmingham-UK
}

(Accepted for Publication: December 8, 2020)

\begin{abstract}
Waste tyres, which are produced in every society in numbers that are increasing annually, are impacting the environment and causing serious problems. These materials possess exceptional properties that can be reused as reinforcement materials in the geotechnical engineering industry. This study investigated the effects of tyre shreds that were randomly mixed with sand and clay to enhance their engineering properties. An Atterberg limits analysis, as well as compaction and odometer tests, were performed on china clay with scrap tyres of varying weights $(10,20,30$ and $40 \%)$. The results show that the Atterberg limits of clay decrease in proportion to increases in the volume of tyre shreds. The compaction characteristics of clay decreased with increased tyre-shred contents of 2-6 mm and 12 mesh. Compression and recompression indexes increased gradually with the tyre-shred content of 12 mesh. A series of direct shear strength tests were performed on the sand-shredded tyre mixtures of Levenseat sand and concrete sand using a direct shear box of $10 \mathrm{~cm} \times 10 \mathrm{~cm}$. Two relative sizes of shredded tyres, 12 mesh and 2-6 mm, were mixed with sand of different weight percentages. The results showed a general increase in the shear strength parameters of both types of sand with the addition of the shredded tyres. The maximum shear strength was obtained at optimum shredded tyre content, approximately $20 \%$ for the 2-6 mm shreds and $15 \%$ for the 12-mesh shreds. The results showed that it is possible to use shredded tyres in geotechnical applications.
\end{abstract}

KEYWORDS: Shredded tyre; Sand; Clay; Consistency; Shear strength; Compressibility

\section{INTRODUCTION}

$\mathbf{P}$ opulation growth, accompanied by a vast range of industrial and human activities, has resulted in large volumes of solid waste being generated globally. A large quantity of these waste materials are not reused but are rather disposed of in the limited number of available disposal sites, which may be exhausted in the near future. Millions of tons of waste tyres are generated annually due to the increasing number of cars being driven by people all over the world. This has led to significant concerns about environmental problems posed by municipal solid waste that contains an ever-growing proportion of waste tyres. According to the Council for Development and Reconstruction (CDR), in Lebanon in 2012 the rate of owning a car is one in 2.7, which is similar to advanced industrial counties (Mrad and El-Samra, 2020). In Lebanon the number of passenger cars is expected to be more than 6 million by the year 2020 and will reach 9 million by the year 2035 (Mrad and El-Samra, 2020). Consequently, the local waste tyre production is subjecting to increase with the increasing 
number of cars. As maintained by Dickson et al. (2001), the United States generates around 270 million waste tyres each year. According to Hird et al. (2002), in England and Wales, for instance, there are approximately 38 stockpiles of nearly 14 million tyres, a quantity that is essential for finding beneficial ways of recycling and reusing tyres. The European Tyre Recycler Association ETRA (1998) reported that there were 250 million used tyres in the European Union; a noticeable number of tyres are stockpiled in other countries, resulting in an accumulation of more than a billion used tyres per annum throughout the world. Discarded waste tyres deposited in open spaces cause major environmental and human health problems.

Some studies have shown that the use of scrap tyres is beneficial in civil engineering applications, particularly in the field of geotechnical engineering. The use of tyre shreds in construction conserves natural aggregate resources, eliminates their disposal cost, reduces stockpiles of waste tyres, which are prone to fire and health hazards, and eliminates damage to structures made of tyre shred soil mixtures (Yoon et al., 2006).

Increasing efforts have been made to find applications for such materials in the field of civil engineering. For example, waste tyres are used

- for reinforcing soft soil in road construction;

- as lightweight material for backfilling in retaining structures;

- for stabilising slopes;

- for controlling ground erosion;

- as sound barriers;

- as aggregates in leach beds of landfills;

- as sources for creating heat;

- for limiting freezing depth;

- as an additive material with asphalt;

- for vibration isolation;

- as a fuel supplement in coal-fired boilers;

- as cushioning foams;

- for low-strength but ductile concrete (Ghazavi,
2004).

On the other hand, the disadvantages of using shredded tyres alone as fill material include self-heating mechanisms, compaction problems and high deformation (Youwai and Bergado, 2003). It is also important to consider any possible environmental implications before using tyre shreds in geotechnical applications. Such implications include potential groundwater contamination (Lee et al., 1999). Edil and Bosscher (1992) indicated that shredded tyres do not illustrate any possibility of becoming a dangerous waste material or of having adverse effects on the quality of groundwater. Degradation of tyre shreds can be due to microbial action and ultra-violet light (Yoon et $a l .$, 2006). Some study indicates that the effect of micro-organisms on scrap tyres is not well understood and Carbon black present in tyres blocks the damaging ultra-violet component of sunlight (Yoon et al., 2006). Further research into the degradation of tyre shreds is required.

Studies by Ahmed (1993) and Ahmed and Lovell (1993) revealed that the shear strength increased as the tyre chip content increased in the sand-tyre chip mixtures with optimum content of $30 \%$ tyre chips by volume. Edil and Bosscher (1994) report that the addition of $25 \%$ tyre chips (20 to $80 \mathrm{~mm}$ ) increased the shear strength of the sand at low normal stresses. Foose et al. (1996), Tatlisoz et al. (1998) and Youwai and Bergado (2003) conducted large-scale direct shear tests to study the mechanical effect of using shredded waste tyres to reinforce sand. They investigated six factors that affect the shear strength of mixtures of sand and tyre shreds: normal stress, shred content, soil matrix, unit weight of a mixture, shred length and shred orientation. They found that sand matrix and shred content are the most important characteristics affecting the shear strength of the mixture. Lee et al. (1999) studied the behaviour of sand and tyre chips to determine the stress-strain relationship of the mixture and 
observed the dilatancy behaviour of rubber sand between pure chips and pure sand. Ghazavi and Sakhi (2005) conducted large shear box tests on sand reinforced with shredded waste tyres and studied the usefulness of optimising the size of waste tyre shreds on shear strength parameters. Attom's (2006) direct shear tests of mixtures of sand and shredded tyres showed that the shear strength and angle of internal friction improved with the addition of shredded waste tyres. Bali et al. (2016) investigated that the shear strength properties of sand-tyre chips mixture increased as the tyre chip of $20 \times 10 \mathrm{~mm}$ content increased, the optimum percentage of the shredded tyre is in the range of $30-40 \%$ by weight. A study by Ghazavi et al. (2011) demonstrated that the shear strength and friction angle decreased for tyre-shred contents beyond $20 \%$ by weight. Mashiri et al. (2015) observed that shredded tyre chips significantly improve the shear strength properties and the reduction in dilatancy behaviour of sand-tyre chip mixtures. Sand-tyre shred mixtures showed an increase in shear strength up to $30 \%$ by weight and were then reduced by direct shear tests (Bałachowski and Gotteland, 2007; Singh and Vinot, 2011, 2013).

Other geotechnical properties were also studied, such as Atterberg limits and compaction and compressibility. Cetin et al. (2006) and Oikonomou and Mavridou (2009) observe that Atterberg's limits decreased as the percentage of the tyre shreds increased or the clay content decreased. Foose et al. (1996) and Cetin et al. (2006) agree that the addition of tyre shreds lowers the maximum dry unit weight. The dry densities of clay mixed with tyre shreds were reduced as the percentages of shreds increased, and there was not a distinct relationship between the size of the shredded tyre and the unit weight that was achieved (Cetin et al., 2006; Daud et al., 2015). For reinforcing expansive soils the coarser tyre shreds slightly outperformed the finer tyre shreds and the $10 \%$ tyre shreds were found to be the optimum choice (Soltani et al.,
2019). The compressibility of soil mixed with tyre material was increased significantly (Edil $e t$ al., 1990; Srivastava et al., 2014).

However, the California bearing ratio (CBR) for clay increased with the addition of shredded tyre (Daud et al., 2015; Kolhe and Langote, 2018). The crumb rubber-sand mixture with the crumb rubber of $30 \%$ by weight was observed to be the most appropriate filler material which resulted in a better performance in the wall compared to the other mixing ratios (Tajabadipour and Marandi, 2017). Chenari et al. (2017) found that the inclusion of shredded tyre to sand decreases settlement reduction factor and increases bearing capacity ratio. Rahgozar and Saberian (2016) discovered that tyre shred significantly enhanced the peat soil geotechnical properties, the mixture showed the highest unconfined compressive strength with the inclusion of $10 \%$ tyre shred. It has also noticed that the addition of small pieces rubber up to $5 \%$ in the clayey soil improves the California bearing ratio, and increase the split tensile strength and unconfined compressive strength (Yadav and Tiwari, 2018). The coefficient of permeability for clay increases with an increase in the percentage of the tyre shreds.

The aim of this study was to investigate the engineering effect of using shredded waste tyres as soil reinforcement material by examining the effects of these tyres on shear strength, compaction and Atterberg limits parameters and compressibility when the tyre shreds are randomly mixed with sand and clay. The effects of varying tyre-shred content and tyre sizes on soil characteristics were also evaluated.

\section{MATERIALS}

\subsection{Sandy soils}

The sands used in the study were Levenseat sand and concrete sand, as shown in Figure 1. Levenseat sand, fine-grained and light in colour, consists of sub-angular particles and features a high silica content, while concrete sand is 
coarse-grained, tan to light brown in colour, with particles that are sub-angular to round in shape.
The soil properties of both sands are shown in Table 1.

Table (1): Properties of concrete sand and Levenseat sand

\begin{tabular}{ccc}
\hline Property & Concrete Sand & Levenseat Sand \\
\hline Specific gravity, Gs & 2.61 & 2.69 \\
\hline Particle size range $(\mathrm{mm})$ & $0.075-4.75$ & $0.05-1.18$ \\
\hline Bulk density $\left(\mathrm{t} / \mathrm{m}^{3}\right)$ & 1.60 & 1.38 \\
\hline Angle of friction $\left({ }^{\circ}\right)$ & 40.3 & 42.9 \\
\hline Absorption $(\%)$ & 1.2 & 1.5 \\
\hline $\mathrm{pH}$ & 6.7 & 7.0 \\
\hline
\end{tabular}

\subsection{Clay soil}

China clay, a commercial clay that is primarily manufactured from the hydrated aluminosilicate clay mineral kaolinite, was used in the study (Figure 1). This clay features a fine particle-size distribution; its particles are flat in shape and soft in texture. Particle-size distribution has an influence on the colour, dispersion, plasticity and strength of soil. The soil properties of china clay are shown in Table 2.

Table (2): Properties of china clay

\begin{tabular}{ccccccc}
\hline $\begin{array}{c}\text { Specific Gravity } \\
\text { (Gs) }\end{array}$ & $\begin{array}{c}\text { Liquid Limit } \\
(\%)\end{array}$ & $\begin{array}{c}\text { Plastic Limit } \\
(\%)\end{array}$ & $\begin{array}{c}\text { Plasticity Index } \\
(\%)\end{array}$ & $\begin{array}{c}\text { Linear Shrinkage } \\
(\%)\end{array}$ & $\begin{array}{c}\text { MDD } \\
\left(\mathbf{k g} / \mathbf{m}^{3}\right)\end{array}$ & $\begin{array}{c}\text { OMC } \\
(\%)\end{array}$ \\
\hline 2.65 & 55 & 29 & 26 & 2.86 & 1478 & 28.2 \\
\hline
\end{tabular}

\subsection{Tyre shreds}

Three sizes of chip types were used in this experimental investigation: $2-6 \mathrm{~mm}, 12 \mathrm{mesh}$ (1.6-0.5 mm) and 50 mesh, as shown in Figure 1. It was difficult to obtain a single size of tyre shreds to use in this investigation; the small tyre pieces were used because of the limited testing facilities. Additionally, as is consistent with many studies described in the literature, the majority of the tests were carried out on waste tyre shreds longer than $10 \mathrm{~mm}$. All the chip types mixed with the soils were free of steel and wires. Some properties of tyre shreds are as follows: specific gravity 1.13-1.36 (Youwai and Bergado, 2003), density 500-600 kg/m $\mathrm{m}^{3}$ (Wu et al., 1997) and absorption 1-2.5\% (Lee et al., 1999). en.shevan@yahoo.com, hussein.hassan@uod.ac,_a.faramarzi@bham.ac.uk ${ }^{1}$ Corresponding author: Directorate of Roads and Bridges in Duhok, Kurdistan Region, Iraq. 


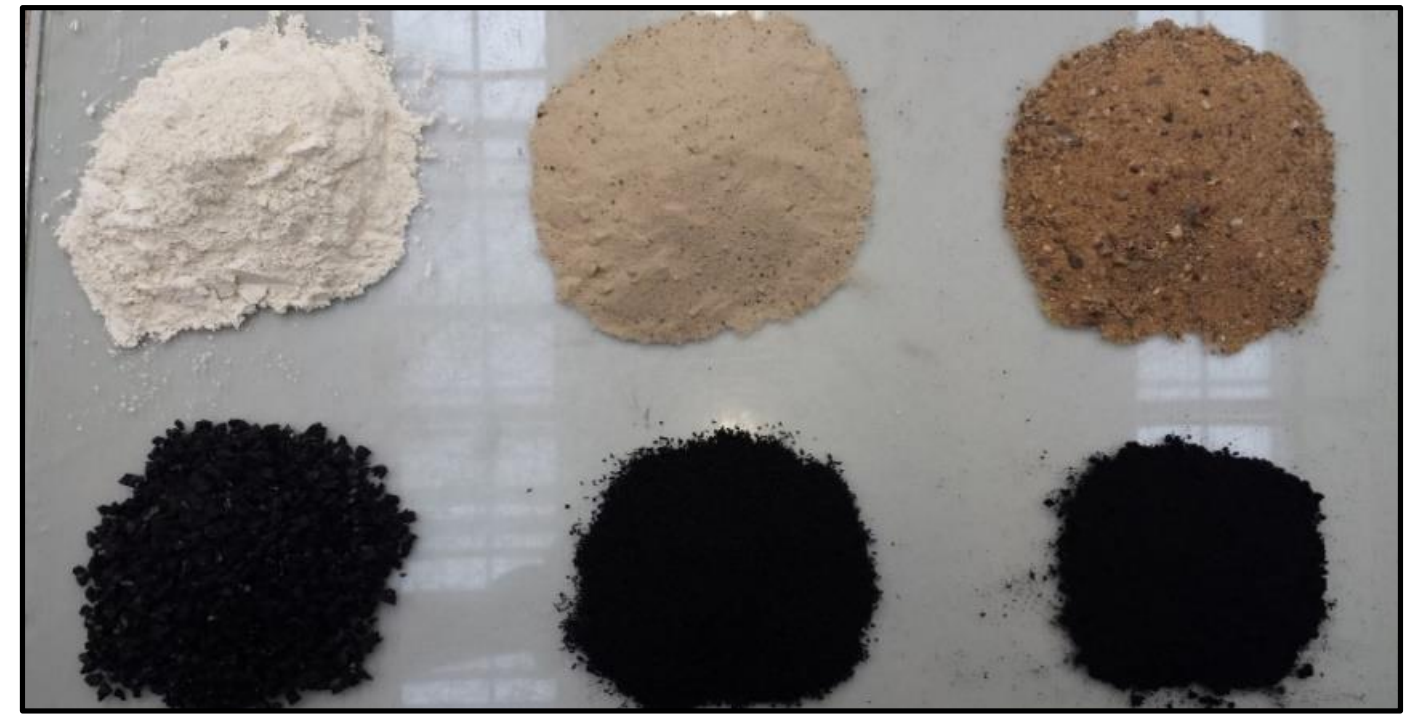

Fig. (1): Top: China clay (left), Levenseat sand (middle), concrete sand (right).

Bottom: shredded tyre 2-6 mm (left), 12 mesh (middle), 50 mesh (right)

\section{METHODOLOGY}

Atterberg limits tests, in accordance with British Standard (BS) 1377-2:1990, were undertaken to investigate the effects of tyre shred material on the liquid limit, plastic limit and plasticity index of china clay. Samples were prepared by mixing china clay with different percentages of tyre shreds of 50 mesh by weight. The liquid limit test was performed by measuring the penetration into the soil specimen via the cone pedometer method. The liquid limit was determined at the cone penetration of 20 $\mathrm{mm}$. The plastic limit is the water content at which soil begins to behave as a plastic material by rolling into $3 \mathrm{~mm}$ diameter threads without crumbling.

The compaction test for specimens was conducted in accordance with BS 1377-4: 1990. This test gave the maximum dry density (MDD) and optimum moisture content (OMC) for mixing china clay with tyre shreds of 12 mesh and 2-6 mm at ratios 0:100, 10:90, 20:80, 30:70 and $40: 60$ by weight. The tests were performed on specimens via the BS light compaction test method (2.5 kg rammer) standard protect. The specimens were prepared according to the above ratios and were then stirred together with water in a mixing bowl for 5 minutes. The sample was compacted in a BS one-litre compaction mould in three layers, with tamping at 27 blows per layer and falling at a height of $300 \mathrm{~mm}$.

Loading and unloading odometer tests, in accordance with BS 1377-5: 1990, were carried out on the china clay containing $0,10,20,30$, and $40 \%$ tyre shreds by dry weight. A tyre shred size of 12 mesh was used in this component of the study. The samples were prepared with results obtained in the compaction test and placed in the odometer ring with a diameter of $75 \mathrm{~mm}$; the initial height of each of the specimens was $19 \mathrm{~mm}$. The specimens were incrementally consolidated to normal stresses of 50, 100, 200, 400 and $800 \mathrm{kPa}$ and gradually rebounded to a normal stress of $200 \mathrm{kPa}$. The compression index $(\mathrm{Cc})$ and the recompression (swell) index (Cr) were determined for china clay and clay-tyre shred mixtures.

A direct shear box test $(10 \mathrm{~cm} \times 10 \mathrm{~cm})$, in accordance with BS 1377-7: 1990, was conducted on the Levenseat sand and concrete sand mixed with four different concentrations of $10 \%, 20 \%, 30 \%$ and $40 \%$ tyre shreds by weight for both shred sizes of $2-6 \mathrm{~mm}$ and 12 mesh.

en.shevan@yahoo.com,_hussein.hassan@uod.ac,_a.faramarzi@bham.ac.uk

$210{ }^{1}$ Corresponding author: Directorate of Roads and Bridges in Duhok, Kurdistan Region, Iraq. 
The mixed materials were carefully placed into the shear box to avoid the segregation of shredded tyres from the sand and were slightly compacted by a small hand tamper. The direct shear testing involved shearing a laterally restrained square soil sample along a horizontal plane. The failure occurred when the shearing resistance reached the maximum value the sample could sustain. The samples were tested under three different normal pressures: 10, 30 and $50 \mathrm{kPa}$. The box was horizontally divided into two halves which could be adequately fixed together by screws that passed vertically through the walls of the upper half and screwed into the lower half. The constant rate of shear stress or displacement rate of $1 \mathrm{~mm}$ per minute was applied in this test.

\section{RESULTS AND DISCUSSION \\ 4.1 Atterberg Limits}

The liquid limit and plastic limit for china clay were $55 \%$ and $29 \%$, respectively. With the addition of tyre shreds, the clay content decreased, and, accordingly, the Atterberg limits decreased, as expected. In general, the results for the clayey soil-tyre shred mixture (Figure 2), showed that as the tyre shreds increased, the liquid limit decreased up to $20 \%$ content of tyre shreds, remained constant up to $30 \%$ and then decreased by up to $40 \%$.

The plastic limit remained almost constant up to $20 \%$, at which point it began to increase up to $30 \%$ and then decreased by up to $40 \%$. According to the results, the effect of tyre shreds on the plastic limits compared to the liquid limit is insignificant. Also, the plasticity index was reduced by increasing the tyre-shred content in the mixture. These results are generally consistent with those obtained by Cetin et al. (2006) and Oikonomou and Mavridou (2009).

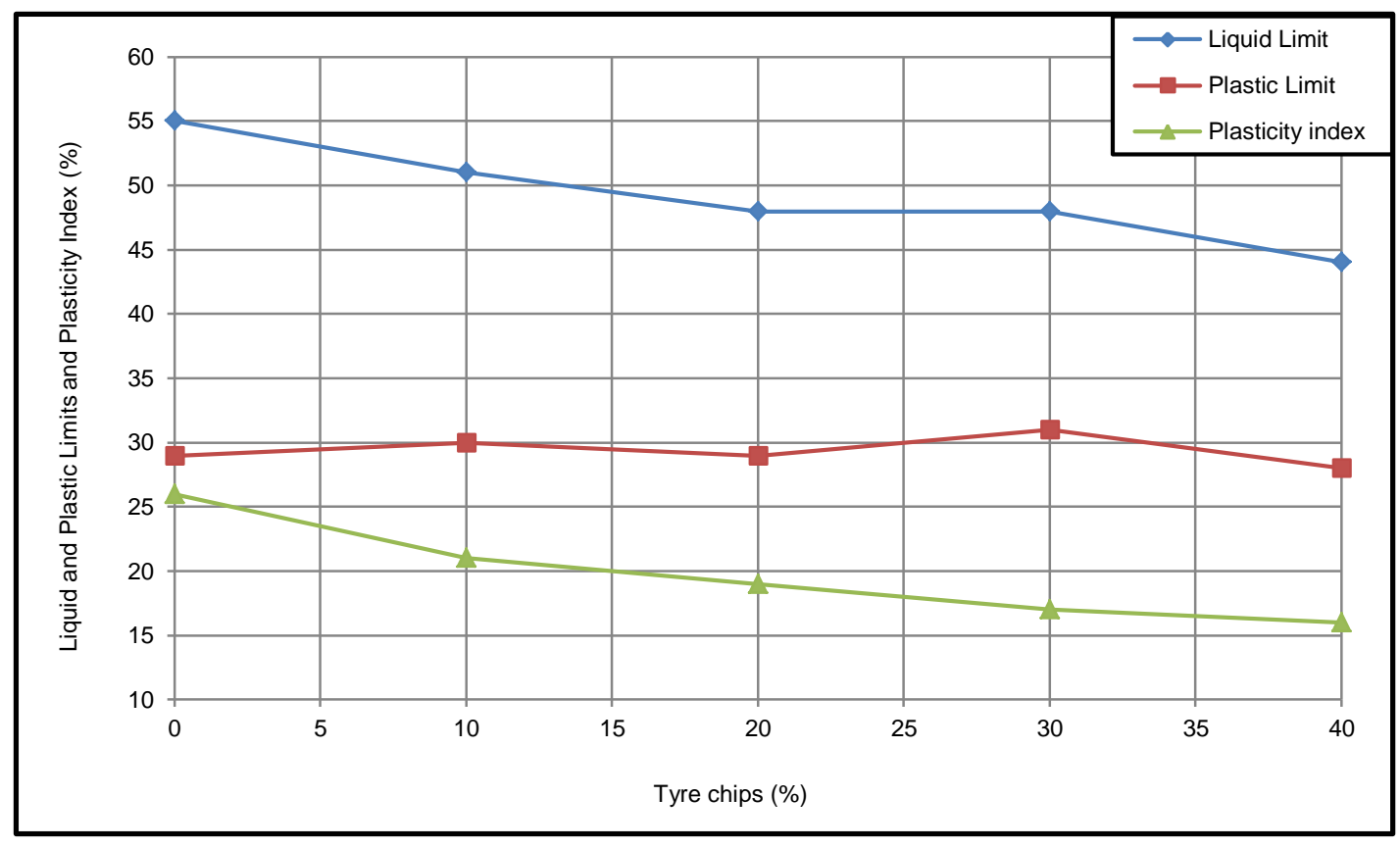

Fig. (2): Variation of liquid and plastic limits and plasticity index for clay as tyre chip increases

en.shevan@yahoo.com, hussein.hassan@uod.ac,_a.faramarzi@bham.ac.uk ${ }^{1}$ Corresponding author: Directorate of Roads and Bridges in Duhok, Kurdistan Region, Iraq. 


\subsection{Compaction Test}

The Proctor curves (Figure 3) clearly demonstrate that the MDD and OMC were higher only for the clayey soil and decreased as the percentage of tyre shreds increased, both for the 2-6 $\mathrm{mm}$ and the 12-mesh tyre shred soil mixtures. This result, which is similar to that reported by Tatlisoz et al. (1997) and Kolhe and Langote (2018), may be due to the lower specific gravity of the shredded tyre and to changes in the particle size distribution and organic content. In addition, a reduction in the OMC may be due to a lower absorption of tyre shreds compared to that occurring in china clay. The reduction in the OMC is in contrast to the result reported by Daud et al. (2015) which OMC is increased with the increase of tyre shred $(1-5 \mathrm{~mm})$ to clayey soil.

The curves demonstrate that the maximum dry unit weight systematically decreased as shred content increased (Ahmed and Lovell, 1993). These results, which are similar to that obtained by Cetin et al. (2006) and Oikonomou and Mavridou (2009), show good potential for using scrap tyres as lightweight fill material. However, the use of finer-size tyre shreds decreased the MDD of china clay relatively more significantly when compared to the corresponding values of MDD obtained with coarser-size tyre shreds. This was due to the density of the $2-6 \mathrm{~mm}$ tyre, which is slightly higher than the 12-mesh size.
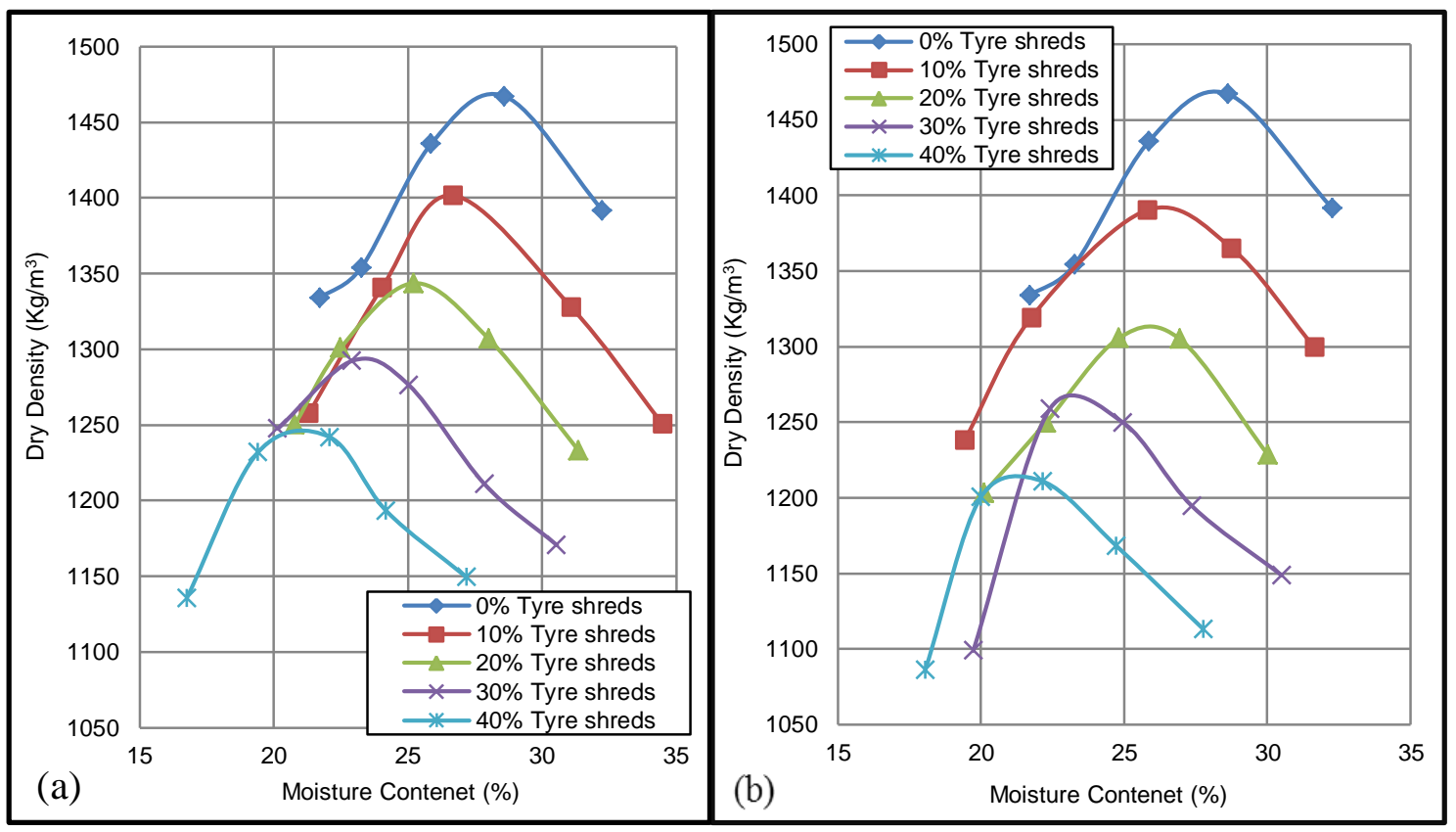

Fig. (3): Compaction curve for 2-6 mm (a) and 12 mesh (b) tyre shred-china clay mixtures

\subsection{Loading-Unloading Odometer Tests}

A complementary test program under odometer conditions was also performed because the compressibility of tyre materials is high, and its specific weight is approximately less than half that of the clay. The purpose of the test was to obtain additional information on the mechanical behaviour of clay with tyre shreds. According to the logarithm pressure and void ratio curve (e-log $\mathrm{p})$, the addition of tyre shreds caused a reduction in the void ratio, which resulted in a stronger material. The slope of the linear portion of the pressure void ratio curve on a semi-log plot is represented by the Cc. The Cc of china clay increases gradually with the inclusion of tyre-shred content, as shown in Figure 4. The $\mathrm{Cr}$ is the slope of the (e-log p) plot during decompression or unloading. For all

en.shevan@yahoo.com,_hussein.hassan@uod.ac,_a.faramarzi@bham.ac.uk

$212{ }^{1}$ Corresponding author: Directorate of Roads and Bridges in Duhok, Kurdistan Region, Iraq. 
tested samples, the $\mathrm{Cr}$ was smaller than the $\mathrm{Cc}$ and increased with the inclusion of tyre-shred content (Figure 4), results which are in agreement with Srivastava et al. (2014). The compressibility of soil mixed with tyre shreds was found to increase significantly for tyre percentages of more than $30 \%$ by weight (Edil et al., 1990). Edil and Bosscher (1994) suggested that the use of backfill comprising soil mixed with tyre shreds may be less compressible than those consisting of pure tyre chips.

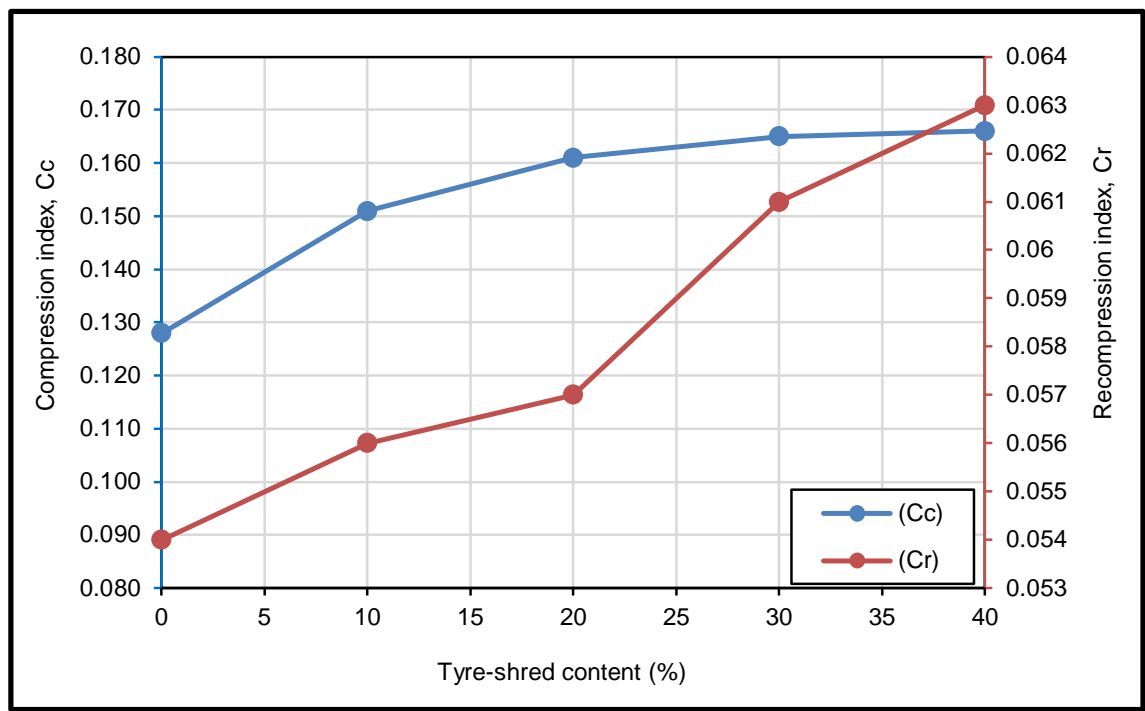

Fig. (4): Effects of shredded tyre content on compression and recompression indexes of clay

\subsection{Direct Shear Test}

\subsubsection{Peak Shear Stresses}

Maximum shear stresses were achieved by using load displacement curves at different applied normal stresses of 10,30 and $50 \mathrm{kPa}$ (Table 3). The failure was taken to correspond to $15 \%$ shear strain. The increment of shreds to Levenseat sand and concrete sand enhanced their peak shear stresses to an optimum amount, after which they reduced. It should be noted that a high shear displacement was required to mobilise the peak shear stress with an increased shredded-tyre content in the composite. In the tyre shred-sand mixture, the shear stress development for long tyre shreds $(2-6 \mathrm{~mm})$ was higher compared to that of the small-size tyre shreds (12 mesh). This difference could be attributed to the larger tyre shred size having a larger contact area with the sand: when randomly distributed in sand, the larger shreds acted as anchors in the shear zone and thus increased the shear resistance compared to that of the smaller-size shred. Gray and Al-Refeai (1986) explain that the random inclusion of tyre shreds in sand, variously positioned in the shear zone such as inclined and vertical, contribute to the shear reinforcement mechanism and thus increase the maximum resistance of sand during shear testing. 
Table (3): Peak shear stresses for sand-tyre shred mixtures

\begin{tabular}{|c|c|c|c|c|c|c|c|c|c|c|c|c|}
\hline \multicolumn{13}{|c|}{ Peak Shear Stresses (kPa) } \\
\hline \multirow{6}{*}{ Tyre Shreds \% } & \multicolumn{6}{|c|}{ Concrete Sand } & \multicolumn{6}{|c|}{ Levenseat Sand } \\
\hline & \multicolumn{6}{|c|}{ Applied Normal Stresses (kPa) } & \multicolumn{6}{|c|}{ Applied Normal Stresses (kPa) } \\
\hline & \multicolumn{2}{|c|}{10} & \multicolumn{2}{|c|}{30} & \multicolumn{2}{|c|}{50} & \multicolumn{2}{|c|}{10} & \multicolumn{2}{|c|}{30} & \multicolumn{2}{|c|}{50} \\
\hline & \multicolumn{6}{|c|}{ Shred size } & \multicolumn{6}{|c|}{ Shred size } \\
\hline & 12 & $2-6$ & 12 & $2-6$ & 12 & $2-6$ & 12 & $2-6$ & 12 & $2-6$ & 12 & $2-6$ \\
\hline & mesh & $\mathrm{mm}$ & mesh & $\mathrm{mm}$ & mesh & $\mathrm{mm}$ & mesh & $\mathrm{mm}$ & mesh & $\mathrm{mm}$ & mesh & $\mathrm{mm}$ \\
\hline $0 \%$ & 12.18 & 12.18 & 24.94 & 24.94 & 46.11 & 46.11 & 10.73 & 10.73 & 26.10 & 26.10 & 47.85 & 47.85 \\
\hline $10 \%$ & 12.47 & 12.18 & 27.84 & 25.81 & 47.85 & 47.85 & 13.63 & 13.63 & 31.61 & 31.61 & 50.46 & 50.46 \\
\hline $20 \%$ & 12.49 & 15.08 & 27.84 & 31.32 & 47.50 & 53.65 & 12.47 & 15.95 & 30.16 & 34.22 & 50.17 & 55.10 \\
\hline $30 \%$ & 11.31 & 13.63 & 26.10 & 29.58 & 41.18 & 46.11 & 11.02 & 13.34 & 28.71 & 33.93 & 45.82 & 53.65 \\
\hline $40 \%$ & 9.28 & 9.57 & 23.20 & 23.20 & 34.80 & 40.89 & 10.15 & 13.92 & 24.07 & 30.45 & 40.60 & 52.49 \\
\hline
\end{tabular}

However, some samples of concrete sand-tyre shred $(2-6 \mathrm{~mm})$ mixtures were placed into the shear box in three layers, and each layer was compacted using a hand tamper to observe the effects of compaction on shear strength by comparing peak shear stresses to those of the specimens placed into the shear box in one layer.
As shown in Table 4, the peak shear stresses for samples placed into the shear box in three layers are higher than those for the samples placed in one layer; this was clearly shown in high normal stresses. The effects of compaction on shear strength might be more apparent with the use of a large direct shear box test.

Table (4): Peak shear stresses for concrete sand-tyre shred (2-6 mm) mixtures

\begin{tabular}{ccccccc}
\hline Tyre Shreds \% & \multicolumn{3}{c}{ One Layer } & \multicolumn{3}{c}{ Three Layers } \\
\cline { 2 - 7 } & \multicolumn{3}{c}{ Applied Normal Stresses } & \multicolumn{3}{c}{ Applied Normal Stresses } \\
& \multicolumn{3}{c}{$(\mathrm{kPa})$} & & \multicolumn{3}{c}{$(\mathrm{kPa})$} \\
\cline { 2 - 7 } & 10 & 30 & 50 & 10 & 30 & 50 \\
\hline $0 \%$ & 12.18 & 24.94 & 46.11 & 10.73 & 26.10 & 47.85 \\
\hline $10 \%$ & 12.18 & 25.81 & 47.85 & 12.47 & 33.64 & 52.78 \\
\hline $20 \%$ & 15.08 & 31.32 & 53.65 & 15.08 & 34.22 & 55.39 \\
\hline $30 \%$ & 13.63 & 29.58 & 46.11 & 13.92 & 31.61 & 47.56 \\
\hline $40 \%$ & 9.57 & 23.20 & 40.89 & 10.15 & 24.07 & 42.60 \\
\hline
\end{tabular}

\subsubsection{Mohr-Coulomb Failure Envelopes}

Coulomb failure envelopes were generated by using the peak shear stresses at different applied normal stresses of 10,30 and $50 \mathrm{kPa}$. The intercept of the failure envelopes on the vertical axis represented the apparent cohesion ( $c^{\prime}$ ) of the composite, while the inclination to the horizontal axis was the angle of internal friction $(\varphi$ '). The nonlinear variation of maximum shear stress at failure led to the appearance of cohesion for the different concentrations of sand-tyre shred mixture (Foose et al., 1996). The friction angle increased at $20 \%$ tyre-shred content and decreased with higher concentrations (Figures 5).

en.shevan@yahoo.com, hussein.hassan@uod.ac, a.faramarzi@bham.ac.uk

$214{ }^{1}$ Corresponding author: Directorate of Roads and Bridges in Duhok, Kurdistan Region, Iraq. 

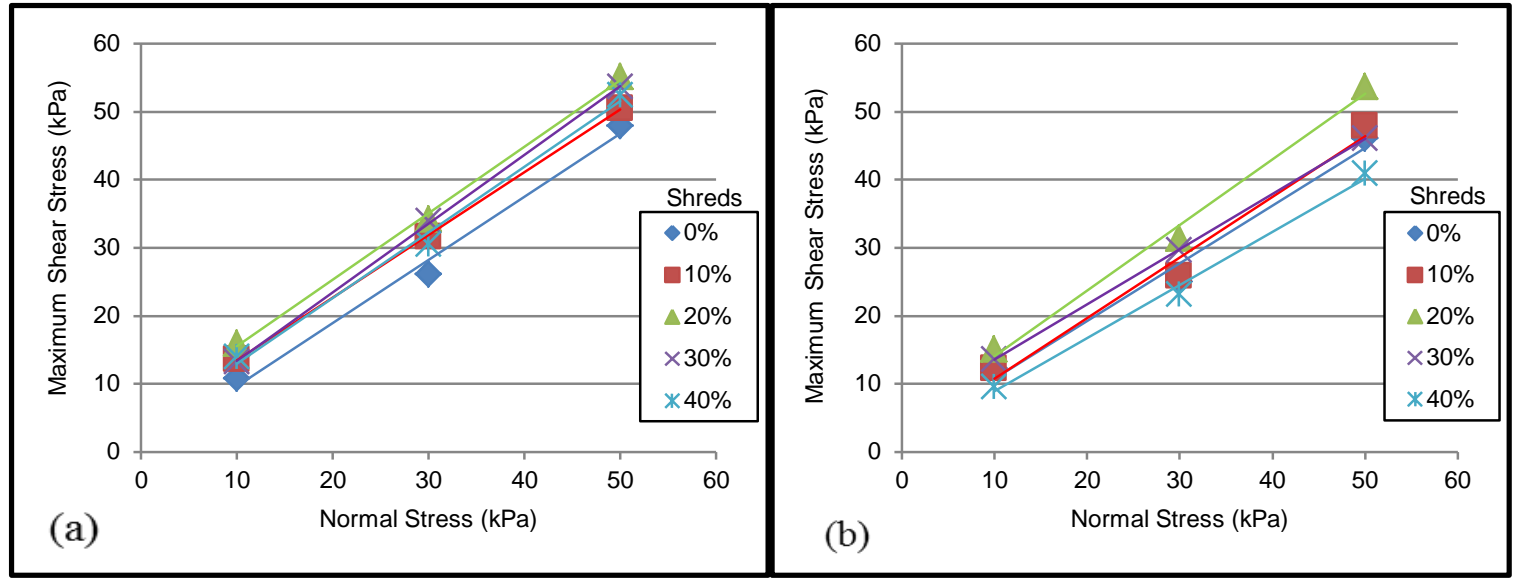

Fig. (5): Mohr-Coulomb failure envelopes for (a) Levenseat sand and (b) concrete sand with inclusion of 2-6 mm tyre shreds

\subsubsection{Effects of Tyre Shreds on Friction Angle and Cohesion of Sand}

The Levenseat sand-tyre shred $(2-6 \mathrm{~mm})$ composite showed a better improvement in friction angle and cohesion compared to the other mixtures (Figure 6). The different values of friction angles obtained from all sand-tyre shred mixtures were $44.4^{\circ}$ for Levenseat sand with the addition of the 12 -mesh tyre shreds and $51.7^{\circ}$ for the 2-6 mm shreds. On the other hand, the concrete sand exhibited lower friction angles when mixed with the 12-mesh tyre shreds were $43.1^{\circ}$, but the inclusion of the longer $2-6 \mathrm{~mm}$ shreds achieved a maximum friction angle of $45^{\circ}$ (Figure 6a). All the higher values were obtained at a shredded tyre percentage of $20 \%$, which was consistent with studies by Ahmed (1993) and Ghazavi et al. (2011) and in contrast to the concentration of $10 \%$ reported by Singh and
Vinot (2013). There is small improvement in the cohesion values for Levenseat sand and concrete sand when mixed with tyre shreds. Also, a study by Rahgozar and Saberian (2016) indicated that adding 20\% tyre shred provided the greatest values for the internal friction angle and effective cohesion. The longer $2-6 \mathrm{~mm}$ tyre shreds gave the mixture a higher cohesion than the shorter 12-mesh shreds (Figure 6b). The increased friction angle and small increase in cohesion for this particular size of tyre shreds can be attributed to the interlocking effects between tyre shreds and sand particles. Additionally, the long 2-6 mm tyre shreds had a better reinforcing effect in the shear zone, which contributed to the significant increase in shear resistance of sand compared to the 12-mesh shred size. 


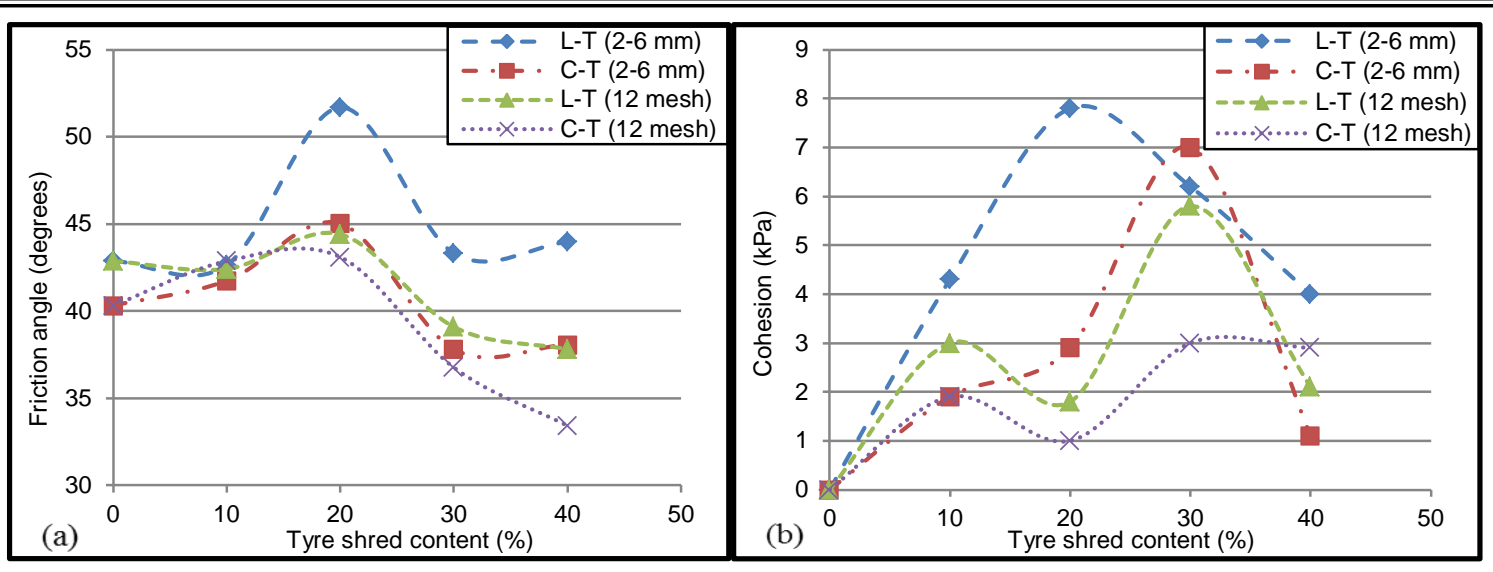

Fig. (6): Effect of tyre-shred content on (a) friction angle and (b) cohesion of Levenseat sand (L-T) and concrete sand (C-T)

\subsubsection{Vertical Deformation and Horizontal Displacement Relationship}

For unreinforced sand, the amount of dilation and contraction depended only on applied normal pressure. The contraction increased as the vertical confining pressure increased, which reduced the sample dilation. For the sand-tyre shred mixture, the vertical deformation depended on both the dosage of tyre shreds in the mixture and on the applied normal pressure. The increased normal pressure and tyre-shred content reduced the dilatant behaviour and increased the contractive behaviour of the test specimen (Figure 7). In Baleshwar and Vianot's (2011) explanation of the reduced dilatant behaviour and increased contractive behaviour during shear strength tests, the authors state that the addition of shredded tyres to sand, as well as the movement of sand particles around the shredded tyres due to the increase in vertical pressure during the shear phase, leads to a dilatancy effect that is less than that which occurs in sand alone, thus increasing the contraction of the composite. These results generally agree with other research, such as that by Lee et al. (1999), Ghazavi (2004), Gotteland et al. (2005) and Mashiri et al. (2015). It can be noted that anomalies in vertical deformation in one test achieved high dilation at high normal pressure compared to that at lower pressure. Figure $7 \mathrm{~b}$ shows almost identical behaviour at both $0 \%$ with $10 \%$ tyre shreds tyre and at $20 \%$ with $30 \%$ tyre shreds. 


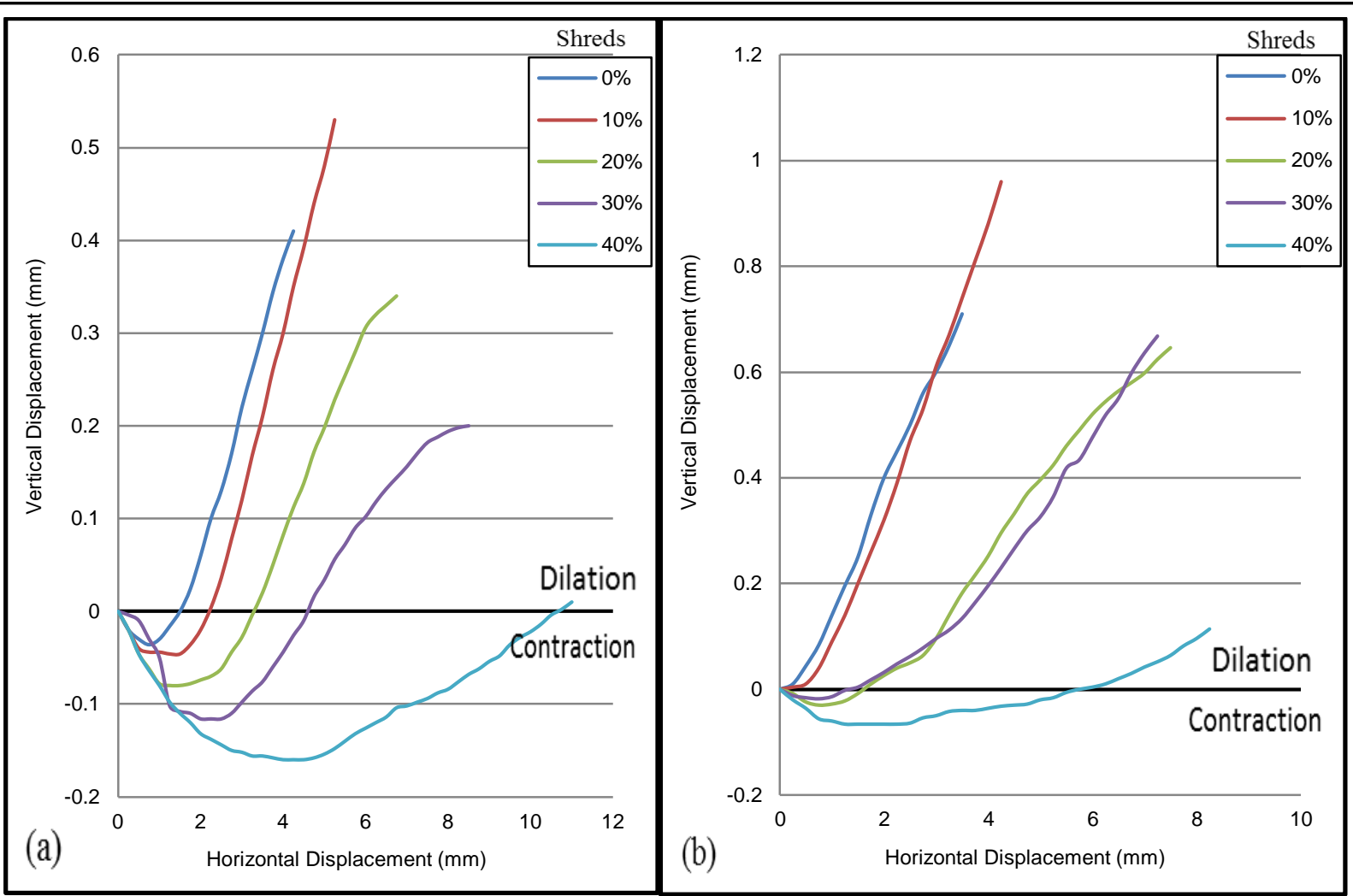

Fig. (7): Variation of vertical displacement with horizontal displacement for concrete sand-tyre shred mixture at normal stresses of (a) $50 \mathrm{kN} / \mathrm{m}^{2}$ and (b) $10 \mathrm{kN} / \mathrm{m}^{2}$

\subsubsection{Effects of Tyre Shreds on Shear Strength of Sand}

A significant improvement of shear strength was observed in both Levenseat sand and concrete sand: with random inclusion with the tyre shreds, the highest values were obtained at a tyre-shred content of $20 \%$ for the 2-6 mm size, as shown in Figure 8. This value were reported similarly by Ahmed (1993), Ahmed and Lovell (1993), Edil and Bosscher (1994) and Tatlisoz et al. (1998). This result is in contrast to the percentage content reported by Tanchaisawat $e t$ al. (2010) and Singh and Vinot (2011), Bali et al. (2016), which is $30 \%$ by weight. Beyond the $20 \%$ optimum percentage for 2-6 mm tyre shreds and $15 \%$ for 12-mesh tyre shreds, there was a reduction in the shear strength. The reduction in the shear strength of mixture beyond the optimum percentage of tyre shreds might be due to decreasing cohesion between particles of sand and tyre shreds, increasing of voids in the mixture and decreasing density of the mixture. In addition, the large tyre shreds appeared to provide a better improvement compared to the smaller size. Moreover, the differences in optimum concentrations of the two sizes might be due to the higher density and better particle correlation of the 2-6 $\mathrm{mm}$ tyre shreds when compared to the 12-mesh tyre shreds, as well as to the larger contact surface area between the sand and the large shreds. For the tyre shred dosage of $20 \%$ in the concrete sand, the shear strength obtained increased from $24.94 \mathrm{kPa}$ to $31.32 \mathrm{kPa}$ for the 2-6 mm size tyre shreds at an applied normal stress of $30 \mathrm{kPa}$, which is an increase of about $25.6 \%$ (Figure 8a). For Levenseat sand, at the $20 \%$ tyre shreds of the $2-$ $6 \mathrm{~mm}$ size, the shear strength increased from $10.73 \mathrm{kPa}$ to $15.95 \mathrm{kPa}$ at an applied normal stress of $10 \mathrm{kPa}$, which is an increase of about $48.7 \%$ (Figure $8 b$ ).

en.shevan@yahoo.com,_hussein.hassan@uod.ac,_a.faramarzi@bham.ac.uk ${ }^{1}$ Corresponding author: Directorate of Roads and Bridges in Duhok, Kurdistan Region, Iraq. 

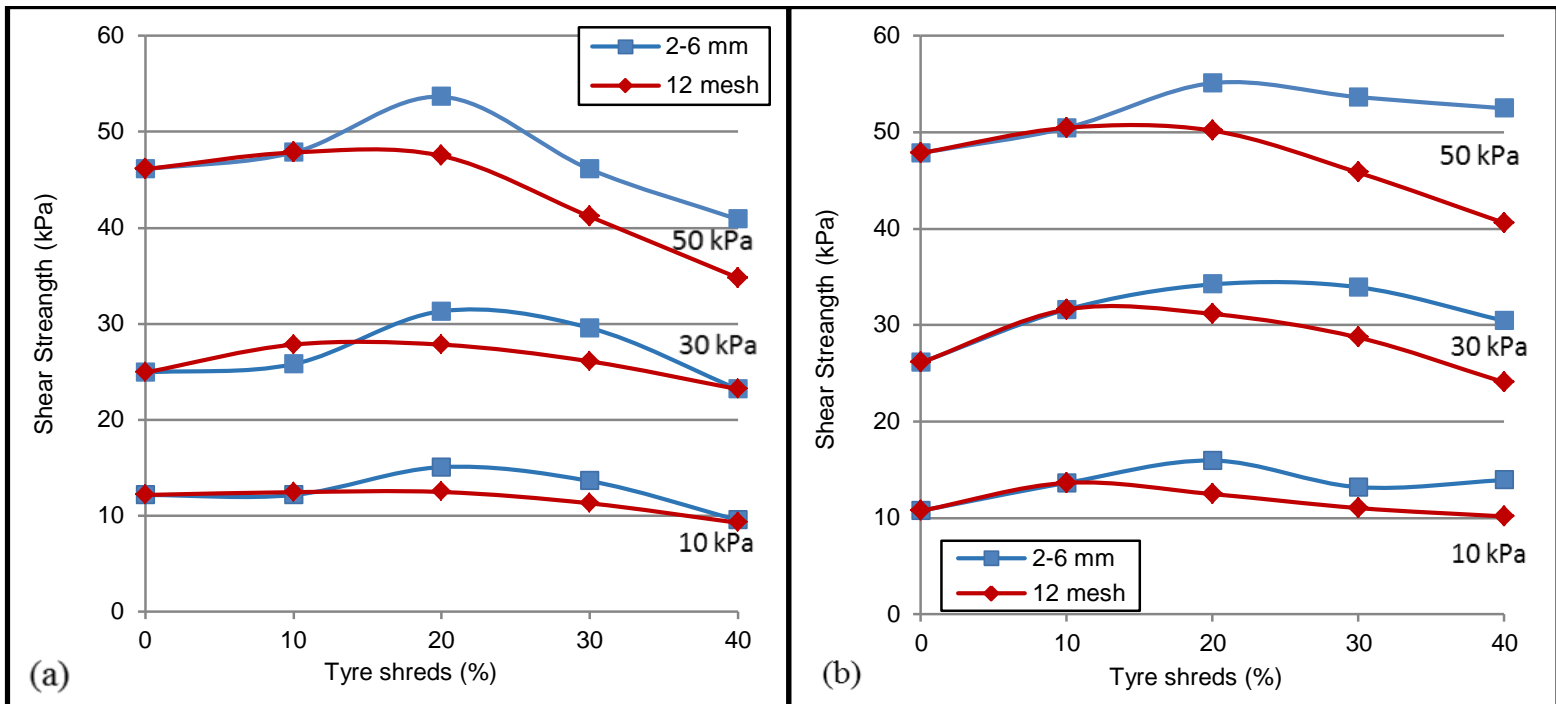

Fig. (8): Shear strength variation with the two tyre shred sizes and applied normal pressures of 10, 30 and $50 \mathrm{kPa}$ for (a) concrete sand and (b) Levenseat sand

\section{CONCLUSIONS}

In this study, the effects of scrap tyre on the geotechnical characteristics of china clay and Levenseat sand and concrete sand were investigated, and the following conclusions were drawn:

- Atterberg limits characteristics mostly decrease with an increased volume of tyre shreds in clay; with the addition of tyre shreds, the clay content decreases.

- The MDD and the OMC decrease with an increasing volume of tyre shreds in clay; this is due to the lower specific gravity and absorption of the tyre material.

- Compression and recompression indexes increased gradually with the shredded tyre content for the clay.

- The inclusion of shredded tyres to the sand generally increased its shear strength parameters and friction angles. The maximum friction angles were achieved at $20 \%$ shred content for both sizes of tyre shreds, while the highest overall shear strength was observed at a concentration of $20 \%$ and $15 \%$ for $2-6 \mathrm{~mm}$ and 12-mesh tyre shred sizes, respectively.

- The longer shredded tyre particles may be desirable as reinforcement material because they achieve a relatively higher shear strength than the shorter tyre shreds, and the shredding has fewer energy requirements.

- The strength parameters of the sand-shredded tyre mixture improved due to the mobilisation of the tensile resistance of the shredded tyres during the shear, which caused the reinforcement of the sand by absorbing the shear load.

- Testing large and undisturbed samples in large direct shear box test are recommended to evaluate its strength and performance. It may be more accurate to determine the results and fairly represented the site.

- The use of shredded tyres may be effective in geotechnical applications as reinforcement material and lightweight fill but with percentages that do not significantly affect compressibility.

\section{Acknowledgements}

This study as a thesis was submitted in partial fulfilment of the degree of Master of Science to School of Civil Engineering, University of Birmingham. The study was supported by the Civil Engineering Laboratories, University of Birmingham, which provided all materials and equipment used for the testing programme. The authors would like to express his gratitude to 
research supervisor Dr Asaad Faramarzi of the University of Birmingham for his inspiring discussions. The authors wish to also thank the technical staff of the Civil Engineering Laboratories.

\section{List of Symbols}

The following symbols used in this paper:

\begin{tabular}{cccc}
\hline Symbol & Description & Symbol & Description \\
\hline$\varphi^{\prime}$ & Angle of internal friction & $\mathrm{kg} / \mathrm{m}^{3}$ & Kilogram per cubic metre \\
\hline${ }^{\circ}$ & Degree & $\mathrm{mm}$ & Millimetre \\
\hline $\mathrm{c}^{\prime}$ & Cohesion & $\mathrm{t} / \mathrm{m}^{3}$ & Ton per cubic meter \\
\hline $\mathrm{MDD}$ & Maximum dry density & $\%$ & Percent \\
\hline $\mathrm{OMC}$ & Optimum moisture content & $\mathrm{pH}$ & Power of hydrogen \\
\hline $\mathrm{CBR}$ & California bearing ratio & $\mathrm{Gs}$ & Specific gravity \\
\hline $\mathrm{Cc}$ & Compression index & $\mathrm{kg}$ & Kilogram \\
\hline $\mathrm{Cr}$ & Recompression (swell) index & $\mathrm{cm}$ & Centimetre \\
\hline $\mathrm{BS}$ & British Standard & $\mathrm{kPa}$ & Kilopascal \\
\hline log p & Logarithm pressure & $\mathrm{kN} / \mathrm{m}^{2}$ & Kilonewton per square meter \\
\hline $\mathrm{e}$ & Void ratio & $\mathrm{ETRA}$ & European Tyre Recycler \\
& & & Association \\
\hline $\mathrm{L}-\mathrm{T}$ & Levenseat sand-Tyre shreds & $\mathrm{CDR}$ & Council for Development and \\
& & & Reconstruction \\
\hline $\mathrm{C}-\mathrm{T}$ & concrete sand-Tyre shreds & et al. & et alia \\
\hline
\end{tabular}

\section{REFERENCES}

Ahmed, I. (1993) Laboratory study on properties of rubber-soils. Report No. fhwa/in/jhrp-93/4, Purdue University, West Lafayette, Indianapolis.

Ahmed, I. and Lovell, C.W. (1993) Rubber soils as lightweight geomaterials. Transportation Research Record No. 1422, National Research Council, Washington, D.C., pp. 61-70.

Attom, M.F. (2006) 'The use of shredded waste tires to improve the geotechnical engineering properties of sands', Environmental Geology, 49, pp. 497-503.

Bałachowski, L. and Gotteland, P. (2007). Characteristics of tyre chips-sand mixtures from triaxial tests. Archives of Hydro-Engineering and Environmental Mechanics, 54(1), pp. 25-36.

Baleshwar, S. and Vinot, V. (2011) 'Influence of waste tyre chips on strength characteristics of soils', Journal of Civil Engineering and Architecture, 9(5), pp. 819-827.

Bali Reddy, S., Pradeep Kumar, D., and Murali Krishna, A. (2016). Evaluation of the optimum mixing ratio of a sand-tire chips mixture for geoengineering applications. Journal of Materials in Civil Engineering, 28(2), 06015007.

BS 1377 (1990) Method of test for soils for civil engineering purposes. London: The British Standard Institution.

Cetin, H., Fener, M., and Gunaydin, O. (2006) 'Geotechnical properties of tyre-cohesive clayey soil mixtures as a fill material', Engineering Geology, 88(1-2), pp.110-120.

Chenari, R. J., Karimpour-Fard, M., Shafie, J., and Ghorbanpour, A. (2017). Tire Shreds and Tire Crumbs Inclusion: Contrast Effects on Bearing Capacity of Sand. Electronic Journal of Geotechnical Engineering, 22(9), 3649-3667. en.shevan@yahoo.com,_hussein.hassan@uod.ac,_a.faramarzi@bham.ac.uk ${ }^{1}$ Corresponding author: Directorate of Roads and Bridges in Duhok, Kurdistan Region, Iraq. 
Daud, N. N., Yusoff, Z., and Muhammed, A. (2015, March). Ground improvement of problematic soft soils using shredded waste tyre. In The Sixth Jordanian International Civil Engineering Conference (JICECO6).

Dickson, T.H., Dwyer, D.F., and Humphrey, D.N. (2001) Prototype tyre shred embankment construction. Transportation Research Record 1755, TRB, National Research Council, Washington D.C., pp. 160-167.

Edil, T. B., and Bosscher, P.J., (1992). Development of Engineering Criteria for Shredded or Whole Tires in Highway Applications, Report No. WI, 14-92. Department of Civil and Environmental Engineering, University of Wisconsin-Madison, Wisconsin.

Edil, T.B. and Bosscher, P.J. (1994) 'Engineering properties of tire chips and soil mixtures', Geotechnical Testing Journal, 17(4), pp. 453-464.

Edil, T.B., Bosscher, P.J., and Eldin, N.N. (1990) Development of engineering criteria for shredded or whole tires in highway applications. Department of Civil and Environmental Engineering, University of Wisconsin-Madison, Wisconsin.

ETRA (European Tyre Recycling Association) (1998) Introduction to tyre recycling. Available at: http://www.etra-eu.org/ (Accessed: 19 August 2008).

Foose G.J., Benson C.H., and Bosscher P.J. (1996) 'Sand reinforced with shredded waste tires' Journal of Geotechnical Engineering, 122(9), pp. 760-767.

Ghazavi, M. (2004) 'Shear strength characteristics of sand-mixed with granular rubber', Geotechnical and Geological Engineering, 22, pp. 401-416.

Ghazavi, M. and Sakhi, M.A. (2005) 'Influence of optimized tire shreds on shear strength parameters of sand', International Journal of Geomechanics, 5(1), p. 58-65.

Ghazavi, M., Ghaffari, J., and Farshadfar, A. (2011) 'Experimental determination of waste tire chip-sand-geogrid interface parameters using large direct shear tests', 5th Symposium on
Advances in Science and Technology. 12-17

May 2011, Mashhad, Khorasan, Iran.

Gotteland, P., Lambert, S., and Balachowski, L. (2005)

'Strength characteristics of tyre chips sand mixtures', Studia Geotechnica et Mechanica, 27(1), pp. 55-66.

Gray, D. and Al-Refeai, T. (1986) 'Behaviour of fabric-versus fibre-reinforced sand', Journal of Geotechnical Engineering, 112(8), pp. 804-820.

Hird, A.B., Griffiths, P.J., and Smith, R.A. (2002).Tyre waste and resource management: a mass balance approach. Viridis Report VR2. Available at: http://s3.amazonaws.com/zanran_storage/ww w.massbalance.org/ContentPages/1159112396. pdf (Accessed: 05 February 2003).

Kolhe, P. V and Langote, R. V. (2018). "Performance of Black Cotton Soil Stabilized With Rubber Tyre Shreads". Journal of Geotechnical Studies, 2(2), pp. 1-8.

Lee, J., Salgado, R., Bernal, A., and Lovell, C. (1999) 'Shredded tires and rubber-sand as lightweight backfill', Journal of Geotechnical and Geoenvironmental Engineering, 125(2), pp. 132-141.

Mashiri, M. S., Vinod, J. S., Sheikh, M. N., and Tsang, H. H. (2015). Shear strength and dilatancy behaviour of sand-tyre chip mixtures. Soils and Foundations, 55(3), 517-528.

Mrad, M., and El-Samra, R. (2020). Waste Tire Management: Lebanon Case Study. J Waste Manag Disposal, 3(101), 2.

Oikonomou, N. and Mavridou, S. (2009) 'The use of waste tyre rubber in civil engineering works', in Khatib, J.M. (ed) Sustainability of construction materials. Cambridge, UK: Cambridge University, pp. 213-238.

Rahgozar, M. A., and Saberian, M. (2016). Geotechnical properties of peat soil stabilised with shredded waste tyre chips. Mires and Peat, 18.

Singh B. and Vinot, V. (2011) 'Influence of waste tyre chips on strength characteristics of soils', Journal of Civil Engineering and Architecture, 5(9), pp. 819-827.

en.shevan@yahoo.com, hussein.hassan@uod.ac,_a.faramarzi@bham.ac.uk

$220{ }^{1}$ Corresponding author: Directorate of Roads and Bridges in Duhok, Kurdistan Region, Iraq. 
-Singh B. and Vinot, V. (2013) 'Shredded tyre-sand as fill material for embankment applications', Journal of Environmental Research and Development, 7(4), pp. 1622-1627.

Soltani, A., Taheri, A., Deng, A., and Nikraz, H. (2019). Tyre rubber and expansive soils: Two hazards, one solution. Proceedings of the Institution of Civil Engineers-Construction Materials, 1-17.

Srivastava, A., Pandey, S., and Rana, J. (2014) 'Use of shredded tyre waste in improving the geotechnical properties of expansive black cotton soil', Geomechanics and Geoengineering: An International Journal, 9(4), pp. 303-311. doi: 10.1080/17486025.2014.902121.

Tajabadipour, M., and Marandi, M. (2017). Effect of rubber tire chips-sand mixtures on performance of geosynthetic reinforced earth walls. Periodica Polytechnica Civil Engineering, 61(2), 322-334.

Tanchaisawat, T., Bergado, D.T., Voottipruex, P., and Shehzad, K. (2010) 'Interaction between geogrid reinforcement and tire chip-sand lightweight backfill, Geotextiles and Geomembranes, 28(1), pp. 119-127.

Tatlisoz, N., Benson, C., and Edil, T. (1997). Effect of fines on mechanical properties of soil-tyre chip mixtures, testing soil mixed with waste or recycled materials, ASTM STP 1275, Mark A. In American Society for Testing and Materials. Tatlisoz, N., Edil, T.B., and Benson, C.H. (1998) 'Interaction between reinforcing geosynthetics and soil-tire chip mixtures', Journal of Geotechnical and Geoenvironmental Engineering, 124(11), pp. 1109-1119.

Wu, W.Y., Benda, C.C., and Cauley, R.F. (1997) 'Triaxial determination of shear strength of tire chips', Journal of Geotechnical and Geoenvironmental Engineering, 123(5), pp. 479-482.

Yadav, J. S., and Tiwari, S. K. (2018). Influence of crumb rubber on the geotechnical properties of clayey soil. Environment, Development and Sustainability, 20(6), 2565-2586.

Yoon, S., Prezzi, M., Siddiki, N. Z., and Kim, B. (2006). Construction of a test embankment using a sand-tire shred mixture as fill material. Waste Management, 26(9), 1033-1044.

Youwai, S. and Bergado, D.T. (2003) 'Strength and deformation characteristics of shredded rubber tire-sand mixtures', Canadian Geotechnical Journal, 40(2), pp. 254-264. en.shevan@yahoo.com,_hussein.hassan@uod.ac,_a.faramarzi@bham.ac.uk ${ }^{1}$ Corresponding author: Directorate of Roads and Bridges in Duhok, Kurdistan Region, Iraq. 